Tyndale Bulletin 67.1 (2016) 87-103

\title{
SPIRITUAL WARFARE AND THE CHURCH'S MISSION ACCORDING TO EPHESIANS 6:10-17
}

\author{
Mark D. Owens \\ (psa6717@yahoo.com)
}

\begin{abstract}
Summary
Ephesians 6:10-17 is typically understood as either a call to engage in spiritual warfare with the 'powers' or as a plea for ethical living. While these two interpretations are not necessarily incorrect, they are likely incomplete. More specifically, they do not account for the author's use of Isaiah in verses 14-15 and 17 and how this text summarises the whole of Ephesians. When one considers these two factors, it becomes reasonable to conclude that this text portrays the church as a community of 'divine-warriors' who continue Christ's mission by extending the new creation inaugurated by His sacrificial death and resurrection.
\end{abstract}

\section{Introduction}

The significance of the call to 'put on the whole armour of God' in Ephesians 6:10-17 unfortunately remains a matter of some debate. ${ }^{1}$ This passage seems most often read (especially by laypeople) as a command to engage in spiritual warfare. ${ }^{2}$ Others, who are unwilling to accept the existence of cosmic evil, view the primary function of this

\footnotetext{
All Scripture quotations are from the NRSV unless otherwise noted.

2 E.g. C. Arnold, Ephesians, Power and Magic: The Concept of Power in Ephesians in the Light of its Historical Setting, SNTSMS 63 (Cambridge: CUP, 1989), 66-68; E. Best, A Critical and Exegetical Commentary on Ephesians, ICC (London: T \& T Clark, 1998), 587-88; P. O'Brien, The Letter to the Ephesians, Pillar New Testament Commentaries (Grand Rapids, MI: Eerdmans, 1999), 457, 490. While there is ongoing discussion concerning the identity of the author of Ephesians, the answer to this question does not significantly impinge on the argument of this article. The author of Ephesians will therefore be referred to as 'Paul'.
} 
passage to be an appeal to virtuous living. ${ }^{3}$ D. Reinhard has also recently argued that this text should be understood as a description of the believer's union with Christ with a view to reminding believers of the resources available to combat the disunity effected by the 'powers'. ${ }^{4}$ In general, one could argue that the two primary interpretations of the passage emphasise different aspects of this text. That is, while the spiritual warfare interpretation stresses the nature of the Church's opponents, the Christian virtue interpretation emphasises the ethical qualities associated with the panoply in verses 14-17. The difficulty with these readings is that neither sufficiently accounts for two significant features of this text: 1) the likelihood that Ephesians $6: 10-17$ is a summary of the entire letter; ${ }^{5}$ and 2 ) the use of Isaiah in Ephesians 6:14-17.

When these two factors are accounted for it becomes likely that this passage portrays the church as a community of 'divine-warriors' who continue Christ's mission by extending the new creation. ${ }^{6}$ This thesis will primarily be demonstrated through an intertextual analysis of the allusions to Isaiah 11:5; 52:7; 59:17 in Ephesians 6:14-15 and 17. This paper will also argue that Ephesians 6:10-17 must be understood as a development of the new creation theme in this letter, particularly texts that correlate the mission of the Church with new creation (Ephesians $1: 23 ; 4: 7-16)$. Finally, I will consider some implications for this reading of Ephesians 6:10-17 and suggest that putting 'on the whole

3 E.g. J. Muddiman, The Epistle to the Ephesians, BNTC (New York: Continuum, 2001), 52, 285-86; W. Wink, Naming the Powers: The Language of Powers in the New Testament (Philadelphia: Fortress, 1984), 89-96. See J. Adewyua, 'The Spiritual Powers of Ephesians 6:10-18 in the Light of African Pentecostal Spirituality', BBR 22 (2012), 254-56, for a recent summary of hermeneutical approaches to interpreting and appropriating Paul's discussion of cosmic evil in Eph. 6:10-18.

4 D. Reinhard, 'Ephesians 6:10-18: A Call to Personal Piety or Another Way of Describing Union with Christ', JETS 48 (2005), 521-32. Interpreters who accept the existence of cosmic evil and read the 'armour of God' subjectively seem to adopt a similar interpretation of this passage (e.g. A. Lincoln, Ephesians, WBC 42 [Dallas: Word, 1990], 459).

5 See O'Brien, Ephesians, 456-60; Lincoln, Ephesians, 432-33, 438-41.

6 For the purposes of this paper, it is assumed that Paul is primarily influenced by Isaianic traditions in Eph. 6:10-17. Given the importance of Isaiah's prophecy within the letter to the Ephesians, it seems prudent to emphasise this background when trying to understand Eph. 6:10-17. See T. Moritz, A Profound Mystery: The Use of the Old Testament in Ephesians, SNT 85 (Leiden: Brill, 1996), 187-95. Some scholars have argued that Paul is also influenced by Wis. 5 and 1 Thess. 5:8 (e.g. T. Neufeld, 'Put on the Armour of God': The Divine Warrior from Isaiah to Ephesians, JSNTSup 140 [Sheffield: Sheffield Academic, 1997]). 
armour of God' is more than a defence against the devil, but instead helps expand the new creation inaugurated by Christ's death and resurrection.

\section{The Isaianic Background of Ephesians 6:10-17}

\subsection{Exegesis of Isaiah 11:5}

Paul's statements in Ephesians 6:14 are often viewed as a subtle allusion to Isaiah 11:5.7

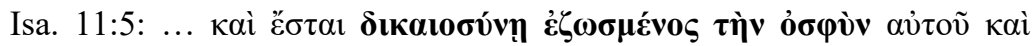

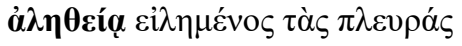

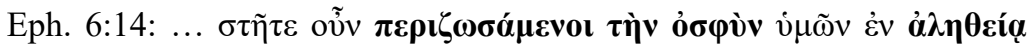

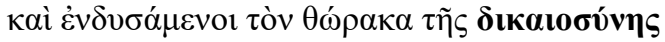

Isaiah 11:5 forms part of the prophet's depiction of the Davidic Messiah responsible for the restoration outlined in Isaiah 10:20-34 (cf. $4: 2 ; 9: 6 ; 11: 1-4)$. Two features of the prophet's portrait of this royal deliverer in Isaiah 11:1-9 are particularly relevant to this discussion. First, the wider context of verse 5 suggests that the Davidic Messiah will oppose the enemies of YHWH and his people as a divine warrior. While there is some degree of uncertainty regarding the nature of the clothing imagery in verse 5, the report of the Messiah's actions against the wicked in verse $4 \mathrm{~b}$ suggests he indeed is to be understood as a divine warrior fighting on behalf of YHWH and his people. According to Isaiah 11:4b, this 'shoot/branch' shall 'strike the earth with the rod of his mouth, and with the breath of his lips he shall kill the wicked'. Second, Isaiah 11:6-9 suggests that the divine warrior's victory will result in the inauguration of the new creation. Importantly, the idyllic imagery found in verses 6-9 is evoked within Isaiah's grand portrait of the 'new heavens and new earth' (cf. 65:25). Ultimately, Isaiah 11:1-9 contributes to a pattern in Isaiah's prophecy whereby divine warrior imagery is closely aligned with a new exodus and the inauguration of the new creation (e.g. 40:1-11; 43:16-21; 49:8-11; 51:9-11). ${ }^{8}$

7 E.g. Moritz, Profound Mystery, 187-90; Neufeld, Divine Warrior, 135.

8 Regarding Isaiah's new exodus, several scholars have recently questioned reading this concept as a historical reference to the return from Babylon. See Ø. Lund, Way Metaphors and Way Topics in Isaiah 40-55, FAT 2.28 (Tübingen: Mohr Siebeck, 2007), 3-21, for an extensive survey of literature on this topic. In general, one can 


\subsection{Exegesis of Isaiah 52:7-12}

Isaiah 52:7-12 may be understood as a hymnic celebration of Zion's deliverance. It is clear from the content of verse 7 that Zion's enemies have been defeated and the victory has been won by none other than God himself. The cry of victory in verse 7 ('your God reigns'), along with the reference to YHWH's 'holy arm' in verse 10, likely depict him as a conquering divine warrior. ${ }^{9}$ The results of YHWH's victory are principally addressed in verses 8-10. There the prophet indicates that YHWH's victory brings forth celebration in the desolated capital city, Jerusalem. The statements within verses 8-10 must be understood in the light of Isaiah's larger message (especially the programmatic text of 40:1-11) and correlate YHWH's victory with the restoration of Zion/Jerusalem. ${ }^{10}$ Despite the absence of concrete links to the descriptions of the 'new heavens and new earth' in Isaiah 65-66, one may nonetheless conclude that the discussion of the restored Zion/Jerusalem in verses 8-10 again links divine conquest with new creation within Isaiah's prophecy. ${ }^{11}$

reasonably conclude that when Isaiah is read as a unitary whole, the goal of the new exodus is the 'new heavens and new earth' of Isa. 65-66 (see esp. Isa. 40:1-11; 49:11-21; 51:9-11; 62:8-11; 65:17-25; 66:18-24). Cf. M. Owens, As It Was in the Beginning: An Intertextual Analysis of New Creation in Galatians, 2 Corinthians, and Ephesians (Eugene, OR: Wipf \& Stock, 2015), 14-42, 187-91; R. Rendtorff, 'Zur Komposition des Buches Jesaja', VT 34 (1984), 318; W. Dumbrell, 'The Purpose of the Book of Isaiah', TB 36 (1985), 111-28. There is thus an inextricable link between Isaiah's new exodus and new creation, and this connection is picked up within Second Temple literature and the New Testament. E.g. Testament of Dan 5.8-13; Sibylline Oracles 3.767-95; Psalms of Solomon 11; 2 Cor. 5:17; Eph. 2:13, 17, 19-22.

9 Cf. J. Blenkinsopp, Isaiah 40-55: A New Translation with Introduction and Commentary, AB 19a (New York: Doubleday, 2002), 342-43; C. Westermann, Das Buch Jesaja: Kapitel 40-66, ATD 19 (Göttingen: Vandenhoeck \& Ruprecht, 1966), 203. Cf. Exod. 6:1, 6; 15:16; 32:11.

10 See J. Oswalt, The Book of Isaiah: Chapters 40-66, NICOT (Grand Rapids, MI: Eerdmans, 1998), 367 and B. Childs, Isaiah (Louisville, KY: Westminster John Knox, 2001), 406 for helpful discussions of the literary relationship between Isa. 40:1-11 and 52:7-12.

11 The prophet's statements in Isa. 62:8-11 are worth noting at this point as they suggest: (1) the description of the restored Zion/Jerusalem in Isa. 60-62 is to be understood as the realisation of Isaiah's new exodus (cf. Isa. 40:3, 10; 43:19; 52:7; Testament of Dan 5.8-13; Sibylline Oracles 3.767-95; 1QM 12.9-18); and (2) the picture of the 'new heavens and a new earth' in Isa. $65: 17-25$ is closely related to the eschatological vision of a restored Zion/Jerusalem in Isa. 60-62. 


\subsection{Exegesis of Isaiah 59:15b-20}

Isaiah 59:15b-20 comprises the divine response to the bleak situation depicted in Isaiah 59:1-15a. Within Isaiah 59:1-15a, the prophet presents an extensive portrait of the depth of Israel's sin. In verse 15b, the prophet depicts YHWH himself assessing and reacting to the spiritual malady of his people. There is a strong sense of parallelism between verse $15 \mathrm{~b}$ and verse $16 \mathrm{a}$ (note the repetition of the phrase $\kappa \alpha i$ $\varepsilon \tilde{i} \delta \varepsilon v)$. Nonetheless, while verse $15 \mathrm{~b}$ deals with the presence of a problem, verse 16a deals with the absence of a solution. The remainder of 59:16b-17 then presents the solution to the plight that has been so extensively depicted in this chapter: YHWH makes war against the chief enemy of his people as a divine warrior. Verse 17 in particular paints this picture of YHWH as a divine warrior preparing for battle by clothing himself with armour, a helmet, a tunic, and a cloak.

While the details of this chapter are certainly not unimportant, the links between this chapter and Isaiah's new exodus theme are particularly relevant to this study. First, new exodus imagery occurs

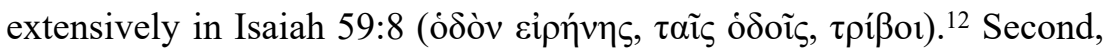
the substantial discussion of Israel's ungodliness in this text recalls the foundational reason for the Babylonian exile (cf. Isa. 40:2; 44:24-25). Third, the mention of YHWH's 'arm' bringing salvation in verse 16 also connects this passage with Isaiah's new exodus theme. ${ }^{13}$ Finally, the theophanic depiction of YHWH as a divine warrior (see Isa. 59:19$20 \mathrm{MT}$ ) also links this text with Isaiah's new exodus (cf. Isa. 40:3-5, 9$11 ; 43: 16-17 ; 51: 9-11 ; 52: 7-10)$.

The links between Isaiah 59:15b-20 and Isaiah's new exodus theme, in turn, shed light on the significance of Isaiah 60-62. These chapters within Isaiah's prophecy may be understood as an extended description of the restored Zion/Jerusalem. ${ }^{14}$ The presence of new exodus and divine warrior imagery in Isaiah 59:15b-20 suggests that Isaiah 60-62 continues the depiction of the restored Zion/Jerusalem as the goal of Isaiah's new exodus. The movement from divine conflict in Isaiah 59:15b-20 to the restored Zion/Jerusalem in Isaiah 60-62 thus reflects the ANE temple-building narrative pattern that is present in Isaiah 40-

\footnotetext{
12 Cf. Isa. 40:3; 42:16; 43:16; 49:11; 52:7. Cf. Oswalt, Isaiah 40-66, 516.

13 Cf. Isa. 40:10-11; 51:9; 52:10.

14 Cf. G. Smith, Isaiah 40-66, NAC 15b (Nashville, TN: B\&H, 2009), 607-609.
} 
55 (e.g. Isa. 40:1-11; 43:16-21; 51:9-11; 52:7-10). ${ }^{15}$ As in Isaiah $52: 7-12$, divine conquest is once again correlated with the inauguration of the new creation (see above).

\section{Ephesians 6:10-17 and Metalepsis}

In his groundbreaking monograph, Echoes of Scripture in the Letters of Paul, R. Hays investigates the use of the Old Testament within the Pauline corpus by means of the literary phenomenon of intertextuality. An important feature of Hays's approach is his suggestion that the relationship between the Pauline corpus and the OT may be profitably understood through the literary phenomenon known as metalepsis. ${ }^{16}$ The relationship between Ephesians 6:10-17 and the prophecy of Isaiah is admittedly a debated issue within the academy. One can safely conclude that most scholars now view Paul's statements in Ephesians $6: 14-15,17$ as conscious allusions to Isaiah $11: 4 ; 52: 7 ; 57: 19 .{ }^{17}$ However, some scholars question the viability of understanding Ephesians 6:10-17 as a metaleptic trope. ${ }^{18}$ For others, the wider context of Isaiah 59:17 is relevant to understanding Ephesians 6:10-17. ${ }^{19} \mathrm{R}$. Cozart goes so far as to suggest that 'the writer [of Ephesians 6] intentionally developed the Isaiah texts from their broad contexts in ways that contribute to the argument of the epistle'. ${ }^{20}$ Cozart's work on

15 Cf. M. Lynch, 'Zion's Warrior and the Nations: Isaiah 59:15b-63:6 in Isaiah's Zion Traditions', CBQ 70 (2008), 245-47; J. Blenkinsopp, Isaiah 56-66: A New Translation with Introduction and Commentary, AB 19b (New York: Doubleday, 2003), 211.

16 R. Hays, Echoes of Scripture in the Letters of Paul (New Haven, CT: Yale University Press, 1989), 20, 87-88, 155.

17 See esp. Moritz, Profound Mystery, 187-95; F. Thielman, 'Ephesians', in Commentary on the New Testament Use of the Old Testament, ed. G. K. Beale and D. A. Carson (Grand Rapids: Baker Academic, 2007), 830-31.

18 E.g. F. Thielman, Ephesians, BECNT (Grand Rapids, MI: Baker Academic, 2010), 419. In his earlier work, Thielman does conclude that Paul was aware of the 'literary contexts' of the Isaianic texts alluded to by Paul in Eph. 6:10-17 ('Ephesians', 832). Some scholars emphasize the image of a Roman soldier as the primary background for Eph. 6:10-17 (e.g. Oepke, TDNT 5:301). Lindemann, Die Aufhebung der Zeit: Geschichtsverständnis und Eschatologie im Epheserbrief, SNT 12 (Gütersloh: G. Mohn, 1975), 89, goes so far as to suggest that there is no allusion to Isaiah's prophecy within vv. 10-17.

19 E.g. Moritz, Profound Mystery, 194-95; O’Brien, Ephesians, esp. 477-79, 482; R. Cozart, This Present Triumph: An Investigation into the Significance of the Promise of a New Exodus of Israel in the Letter to the Ephesians (Eugene, OR: Wipf \& Stock, 2013), 235-49.

20 Cozart, This Present Triumph, 236. 
this passage has helpfully moved this discussion forward by linking Ephesians 6:10-17 with Isaiah's new exodus. However, Cozart fails to consider how Ephesians 6:10-17 might also develop the letter's new creation theme and this is a significant oversight since Isaiah's new exodus is clearly associated with new creation within this letter. ${ }^{21}$ The relationship between Ephesians 6:10-17 and the new creation theme within this letter, in fact, allows one to view this passage as a metalepsis.

Perhaps the best starting point for any discussion of the new creation theme in Ephesians is verse 1:10. There Paul expands upon on his comments regarding the 'mystery' that God has purposed in Christ (v. 9). According to verse 10, this mystery concerns the outworking of God's plan for 'the fullness of time' and involves the unification

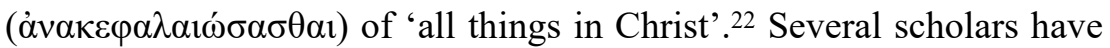
already suggested that this unification 'of all things' in verse 10 is related to the letter's new creation theme and have primarily argued

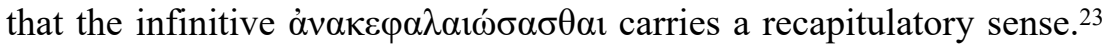
When understood within the context of the entire letter of Ephesians, this action of uniting 'all things' in Christ likely encompasses God's plan to restore the fractured universe (both in terms of humanity and the presence of cosmic evil) that resulted from what is traditionally known as 'the fall'. ${ }^{24}$ Importantly, while there is no explicit reference to the gospel in this passage, the blessings outlined in this passage are indirectly related to the gospel..$^{25}$ Furthermore, Paul will later discuss the 'mystery' of Ephesians 1:9-10 in Ephesians 3:1-13 and there he not

21 Cf. Owens, As It Was in the Beginning, 149-62.

22 The verb $\alpha$ v $\alpha \kappa \varepsilon \varphi \alpha \lambda \alpha$ ió $\omega$ likely refers to the action in which distinct entities are brought together under the framework of a single entity (cf. Owens, As It Was in the Beginning, 129).

23 Cf. Owens, As It Was in the Beginning, 126-30; Lincoln, Ephesians, 33-34; P.

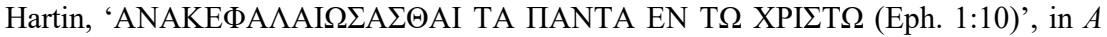
South African Perspective on the New Testament (Leiden: Brill, 1986), 231-34; M. Turner, 'Mission and Meaning in Terms of "Unity" in Ephesians', in Mission and Meaning: Essays Presented to Peter Cotterell, ed. Antony Billington, Tony Lane, and Max Turner (Carlisle: Paternoster, 1995), 139-40; J. McHugh, 'A Reconsideration of Ephesians 1.10b in the Light of Irenaeus', in Paul and Paulinism: Essays in Honour of C. K. Barrett, ed. Morna D. Hooker and Stephen G. Wilson (London: SPCK, 1982), 302-309; pace M. Barth, Ephesians: Introduction, Translation, and Commentary on Chapters 1-3, AB 34a (New York: Doubleday, 1974), 91-92.

24 Cf. C. Caragounis, The Ephesian Mysterion: Meaning and Content, ConBNT 8 (Lund: CWK Gleerup, 1977), 139-45; O'Brien, Ephesians, 111-15.

25 This is especially true of the blessing of 'redemption,' which is contextually identified with 'the forgiveness of sins' (v. 7). 
only explicitly links this 'mystery' with the 'gospel' in verse 6, but also the revelation of God's wisdom to the 'powers' through the church.

The next relevant text within the Ephesian new creation theme is Ephesians 1:23. Paul here describes the 'body of Christ' as 'the fullness of him [Christ] who fills all ( $\tau \grave{\alpha} \pi \alpha ́ v \tau \alpha)$ in all'. This statement presents the would-be interpreter with a number of difficult lexical, grammatical, and theological problems. Two questions, however, are particularly pertinent to this present study: (1) the meaning of the noun $\pi \lambda \eta \dot{\rho} \omega \mu \alpha$; and (2) the voice of the participle $\pi \lambda \eta \rho o v \mu \varepsilon \dot{v o v . ~ I n ~ t e r m s ~ o f ~}$ the first question, most scholars now understand the noun $\pi \lambda \eta \dot{\rho} \rho \omega \alpha$ in close relation to the use of the root $\pi \lambda \eta \rho-$ in the OT and conclude that this noun in Ephesians 1:23 is to be understood in a passive sense. ${ }^{26}$ When read together with the noun $\sigma \tilde{\omega} \mu \alpha$ in v. 23 , the noun $\pi \lambda \eta \dot{\rho} \omega \mu \alpha$ ultimately depicts the Church as the earthly presence and representative of Christ. ${ }^{27}$ With regard to the second question, scholars have generally interpreted the voice of the participle $\pi \lambda \eta \rho 0 v \mu \varepsilon$ vov in three ways: (1) as a passive (i.e., Christ is being filled by the church); (2) as a true middle (i.e., Christ fills the church and the cosmos for himself); and (3) as a middle with an active sense (i.e., Christ fills the church and the cosmos). ${ }^{28}$ Of these three options, most scholars now conclude that it is the final reading that makes the most sense within the context of Ephesians 1:23 (cf. Eph. 3:19; Col. 1:19; 2:9-10). ${ }^{29}$

This reading of Ephesians 1:23, if correct, has significant implications for understanding the portrait of the Church in Ephesians. Ephesians 1:23 clearly correlates ecclesiology and Christology, particularly in terms of Christ's cosmic triumph and God's plan to

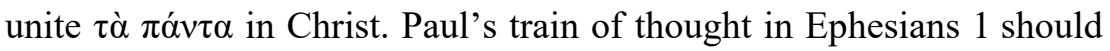

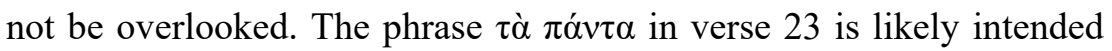

26 E.g. G. Münderlein, 'Die Erwählung durch das Pleroma: Bemerkungen zu Kol. i.19', NTS 8 (1962), 264-76. Cf. O’Brien, Ephesians, 149-50; Best, Ephesians, 187-88.

27 E.g. Lincoln, Ephesians, 74-77; C. Arnold, Ephesians, Zondervan Exegetical Commentary on the New Testament (Grand Rapids, MI: Zondervan, 2010), 118-19.

28 See H. Hoehner, Ephesians: An Exegetical Commentary (Grand Rapids, MI: Baker Academic, 2002), 296-99, for an extensive survey of secondary literature related to the meaning of the participle $\pi \lambda \eta \rho 0 u \mu \varepsilon ́ v o v$ in Eph. 1:23.

29 Cf. Barth, Ephesians 1-3, 205-209; Arnold, Power and Magic, 82-85; R. Meyer, Kirche und Mission im Epheserbrief, SBS 8 (Stuttgart: Katholisches Bibelwerk, 1977), 44-48; Muddiman, Ephesians, 96; R. Schnackenburg, Der Brief an die Epheser, EKKNT 10 (Zürich: Neukirchen-Vluyen, 1982), 79-83; O’Brien, Ephesians, 150; pace Thielman, Ephesians, 114-15; G. Dawes, The Body in Question: Metaphor and Meaning in the Interpretation of Ephesians 5:21-33 (Leiden: Brill, 1998), 242-45. 
as an intratextual allusion back to verse 10, where Paul has introduced God's ultimate goal for the cosmos ('to gather up all things in [Christ]'). Yet Paul's statements in verse 23 clearly expand upon verses 20-22. ${ }^{30}$ Ultimately, when one considers the development of Paul's argument in Ephesians 1 and takes account of the manner in which the Church is depicted in verse 23 (as Christ's 'body' and 'fullness'), it becomes evident that Ephesians 1:23 gives the Church a prominent role in extending the scope of Christ's victory and advancing the new creation inaugurated by his sacrificial death. This conclusion seems particularly warranted if the proclamation of the gospel represents one of the means by which the Church serves as the 'fullness' of Christ. ${ }^{31}$

The final text within Ephesians that is pertinent to this present discussion is Ephesians 4:7-16. There are, of course, a number of complex issues within this segment of Ephesians 4. We may, however, confine ourselves to two subjects: (1) the relationship between Ephesians 4:7-16 and Ephesians 1:20-23; and (2) the flow of thought between Ephesians 4:7-10 and Ephesians 4:11-16. Within Ephesians $4: 7-16$, one finds a number of lexemes and phrases that intratextually link this passage with Ephesians 1:20-23.

Ephesians 4:10-16

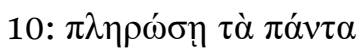

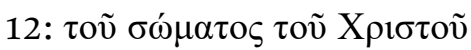

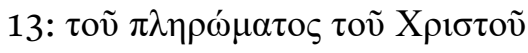

15: $\kappa \varepsilon \varphi \alpha \lambda \eta ́$

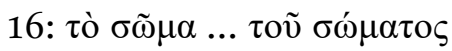

Ephesians 1:20-23

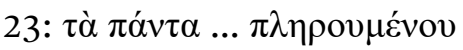

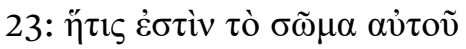

23: $\tau$ ò $\pi \lambda \eta \dot{\eta} \omega \mu \alpha$

22: $\kappa \varepsilon \varphi \alpha \lambda \eta े \nu$

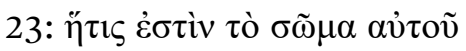

The presence of these intratextual connections has not gone unnoticed by commentators, who frequently argue that the language and thought of Ephesians 4:10 parallels Paul's statements in Ephesians 1:23. ${ }^{32}$ In terms of the logical relationship between Ephesians 4:7-10 and Ephesians 4:11-16, the repetition of the verb $\varepsilon \delta \omega \kappa \varepsilon v$ in verses 8 and 11

\footnotetext{
30 One should, however, conclude that Eph. 1:20-22 and Eph. 1:23 have two different eschatological perspectives. That is, while the description of Christ's victory over the 'powers' in vv. 20-22 strikes a note of inaugurated eschatology, v. 23 could be viewed as something of a theological corrective that draws the reader back to the emphasis on future eschatology found in Eph. 1:10.

31 Cf. Arnold, Ephesians, 119; Meyer, Kirche und Mission, 43-46, 140-41, 144-45.

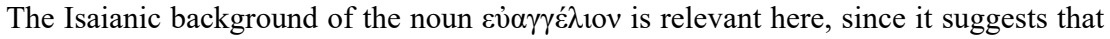
the gospel is ultimately the proclamation of God's victory (cf. Isa. 40:9; 52:7; 61:1).

32 E.g. Arnold, Ephesians, 255; Thielman, Ephesians, 273.
} 
suggests that these two sections of Ephesians 4 are related (cf. Eph.

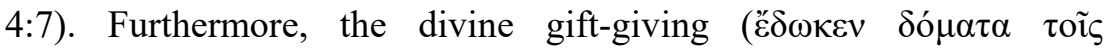
$\dot{\alpha} v \theta \rho \omega ́ \pi 01 \varsigma)$ in Ephesians 4:8 is associated with Christ's heavenly ascension and verse 10 returns to the topic of Christ's ascension by briefly addressing its purpose (cf. Eph. 1:20-22). According to verse

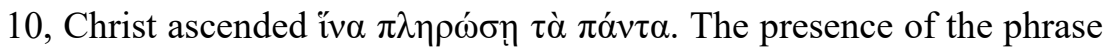
$\tau \grave{\alpha} \pi \alpha ́ v \tau \alpha$ in Ephesians 4:10 suggests that v. 8-10 fundamentally forms part of this letter's new creation theme and relates to God's vision for cosmic reconciliation (cf. Eph. 1:10). When one accounts for the lexical and conceptual links between 4:7-16 and Ephesians 1:20-23, one can reasonably conclude that Paul is again giving the church a substantial role in God's plan 'to gather all things' in Christ. The officials mentioned in Ephesians 4:11 are thus to be viewed as a central feature of this plan and are to be understood as the $\delta$ ó $\mu \alpha \tau \alpha$ referred to in verse $8 .{ }^{33}$ Furthermore, the portrait of the church's growth and unity in verses 12-16 is ultimately correlated with God's intent to restore 'all things' in Christ (cf. Eph. 1:10). ${ }^{34}$

Reading Ephesians 4:7-16 within the new creation theme of this letter also has significant ramifications for understanding the ecclesiology of this letter. For the purposes of this present discussion, the connection that Ephesians 4:7-16 establishes between the ministry of the church and God's plan to unify 'all things' in Christ suggests that the church plays an integral role in extending the scope of the new creation. Once again, a distinction between future eschatology and inaugurated eschatology is helpful for understanding Paul's argument (see above). That is, while Paul certainly seems to envision the partial arrival of the new creation (cf. 2 Cor. 5:17; Gal. 6:15), there is no room to conclude that the new creation has completely arrived. ${ }^{35}$ One of the primary theological contributions of Ephesians is the notion that the people of God perform a vital role in bringing about the manifestation of the new creation in its fullest sense. Ephesians 4:7-16 may thus be understood as Paul's explanation of how the church is to achieve corporately the cosmic objective outlined in Ephesians 1:10.

33 Cf. C. Talbert, Ephesians and Colossians, Paideia (Grand Rapids, MI: Baker, 2007), 112.

34 Cf. O’Brien, Ephesians, 297.

35 This is especially true if Isaiah's 'new heavens and new earth' represents the full realization of Paul's conception of new creation. Cf. Owens, As It Was in the Beginning, 68-170. 


\section{Reading the 'Armour of God' with Isaiah's New Exodus}

Thus far, this article has demonstrated that there is a clear link between the new exodus and new creation within Isaiah's prophecy. In the ensuing analysis, I will argue that Paul continues this link between new exodus and new creation by evoking these Isaianic new exodus texts and correlating them with concepts he has previously developed within this letter. More specifically, I will argue that Ephesians 6:10-17 climactically develops Paul's discussion of new creation and the church's mission. This overall discussion will have strong implications for understanding the significance of this passage.

The first piece of armament Paul exhorts the reader to take up is the 'belt of truth' (verse 14). The noun $\dot{\alpha} \lambda \eta \theta \varepsilon i ́ \alpha$ ('truth') and its derivatives are frequently associated with the gospel in this letter. For example, the

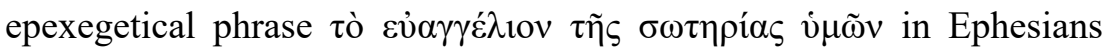

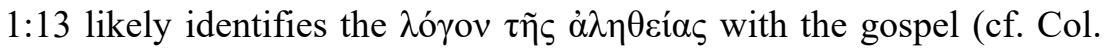
1:5). Similar conclusions may be made regarding the use of the noun $\dot{\alpha} \lambda \eta \theta \varepsilon \dot{\alpha} \alpha$ in Ephesians 4:21 and the participle $\dot{\alpha} \lambda \eta \theta \varepsilon v ́ o v \tau \varepsilon \varsigma$ in Ephesians $4: 15 .{ }^{36}$ One could go so far as to suggest that it is only in Ephesians 4:24 and 5:9 that the noun $\dot{\alpha} \lambda \eta \theta \varepsilon i \alpha$ is used in an abstract sense. A closer look at Ephesians 4:15 and 21 indicates that Paul is granting the gospel a place of central importance within the ministry of the church and the Christian life. With that being said, it is only natural that Paul would begin his description of the panoply in Ephesians 6:14-17 by referencing the gospel. ${ }^{37}$

Paul then summons the reader to don the 'breastplate of

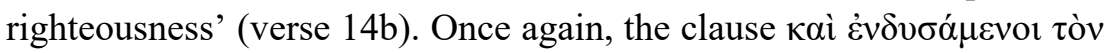

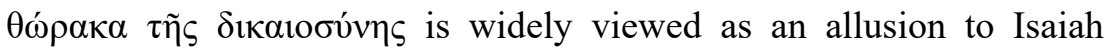
59:17 (see above). There is also the question of whether this piece of weaponry should be understood objectively or subjectively. ${ }^{38}$ The noun

\footnotetext{
36 Since Eph. 4:10-16 discusses at length the mission of the church, one could read these two texts as parallel passages. If that is the case, this would strengthen the likelihood that 'truth' in Eph. 6:14 refers to the gospel.

37 Cf. Neufeld, Divine Warrior, 134; Thielman, Ephesians, 424. Other scholars view 'truth' in Eph. 6:14 more abstractly (e.g. Best, Ephesians, 599) or argue that Paul is describing the need to live in a manner that comports with the gospel (e.g. Arnold, Ephesians, 452; O’Brien, Ephesians, 474).

38 For the objective reading, see M. Barth, Ephesians: Introduction, Translation, and Commentary on Chapters 4-6, AB 34b (New York: Doubleday, 1974), 796, and F. F. Bruce, The Epistles to the Colossians, to Philemon, and to the Ephesians, NICNT
} 


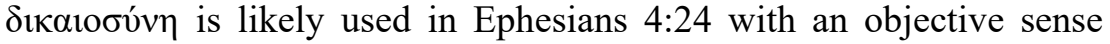
that emphasizes God's innate righteousness, however, it does seem to be used in 5:9 in a subjective manner to stress the appropriate conduct of a Christ-follower. Looking more closely at the immediate context of Ephesians 6:10-17, the reality that the individual pieces of armament

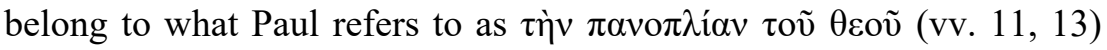
suggests that this righteousness is none other than God's own righteousness. Nonetheless, Paul likely views this divine righteousness subjectively impacting the behaviour of believers as they engage in the conflict against cosmic evil. ${ }^{39}$

Paul's description of the third article of weaponry in verse 15 is more complicated and will require careful examination. First, the preposition $\dot{\varepsilon} v$ in this verse is best read as dative of instrument. ${ }^{40}$ When read in this light, the construction then comes to signify the object with which believers are to bind their feet (see NIV, 'with the readiness'). In terms of the nature of the preparation depicted in verse 15, scholars generally frame this discussion by depicting it either as a defensive posture or an offensive engagement with the 'powers'. Those who favour the latter interpretation generally supply the verb 'to proclaim' and conclude that Paul is calling believers to 'bind their feet with the preparation to proclaim the gospel of peace'.$^{41}$ However, reading the imagery in verse 15 offensively does not fit well with the kind of weaponry referred to. Indeed, Paul is obviously using metaphorical imagery in this passage and it is natural to conceive the gospel as an offensive weapon in the war against cosmic evil (see below). Nonetheless, it stretches the imagery too far to conclude that Paul understands this part of the panoply as an offensive weapon. A defensive reading of Paul's statements in verse 15 therefore conforms best to Paul's actual statements in this portion of his description of the 'armour of God'.

(Grand Rapids, MI: Eerdmans, 1984), 147. The noun is read subjectively by S. Fowl, Ephesians: A Commentary, NTL (Louisville, KY: Westminster John Knox, 2012), 206), D. Wenkel, 'The "Breastplate of Righteousness" in Ephesians 6:14', TynBul 59 (2007), 275-87, and G. Sellin, Der Brief an Epheser, KEK 8 (Göttingen: Vandenhoeck \& Ruprecht, 2008), 481.

39 Cf. Hoehner, Ephesians, 841; Best, Ephesians, 599; Muddiman, Ephesians, 291; Reinhard, 'Ephesians 6:10-18', 524; O’Brien, Ephesians, 474-75; Arnold, Ephesians, 453.

40 Cf. Hoehner, Ephesians, 842.

41 E.g. Arnold, Ephesians, 454-55. 
A defensive reading of verse 15 also best explains Paul's reference to the 'gospel of peace'. This genitive construction is best read as a genitive of source. ${ }^{42}$ Scholars who favor an offensive interpretation of this portion of the panoply tend to understand this construction as an objective genitive (i.e., 'by preparing to proclaim the gospel of peace'). ${ }^{43}$ The problems with an offensive reading of verse 15 have already been discussed. Interpreting the construction as a genitive of source, on the other hand, fits well with Paul's discussion of Christ's peace-making ministry in Ephesians 2:11-18. This portion of Ephesians addresses the union of Jew and Gentile that has been achieved through Christ's sacrificial death and depicts this union as: (1) an act of new creation (see esp. v. 15); and (2) the fulfillment of Isaiah's proclamation of a new exodus. In terms of the relationship between Ephesians 2:11-18 and the fulfillment of Isaiah's new exodus, it is important to first note that it is generally acknowledged that Ephesians 2:13 and 17 allude to Isaiah 52:7 and Isaiah 57:19.44 Interestingly, Ephesians 6:15 is also widely viewed as an allusion to Isaiah 52:7.45 The allusion to Isaiah 52:7 in Ephesians 6:15, in fact, is often used as evidence for understanding the construction 'the gospel of peace' as an objective genitive. ${ }^{46}$ Nonetheless, while there are legitimate grounds for reading Ephesians 6:15 in light of Isaiah's new exodus, Paul's

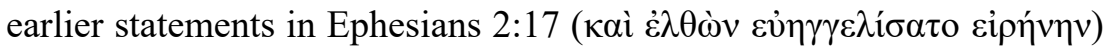
must be given priority. ${ }^{47}$ If the context of Ephesians 2:11-18 is given priority and Christ's ministry is understood as the fulfillment of Isaiah's new exodus, it becomes evident that Ephesians 6:15 exhorts believers to prepare for battle with the forces of cosmic evil by living out and living in light of the victory achieved by Christ. ${ }^{48}$ This way of

42 Cf. Lincoln, Ephesians, 449.

43 E.g. Arnold, Ephesians, 454-55; O’Brien, Ephesians, 477.

44 E.g. A. Lincoln, 'The Use of the Old Testament in Ephesians,' JSNT 14 (1982), 26-28; Moritz, Profound Mystery, 31-32.

45 E.g. Muddiman, Ephesians, 291; Thielman, Ephesians, 426; pace Best, Ephesians, 599-600.

46 E.g. Arnold, Ephesians, 455; Sellin, Epheser, 482; O’Brien, Ephesians, 477.

47 Interestingly, Eph. 2:17 likely evokes Isa. 52:7 within a section of Ephesians that is replete with new creation imagery and concepts. Note especially the use of death-life imagery in Eph. 2:1-6, the use of creation imagery in v. 10, the reference to the creation of a new humanity in v. 15 , and the temple imagery in vv. 19-22. Cf. Owens, As It Was in the Beginning, 131-69.

48 This reading of Eph. 6:15 ultimately recognizes that Isa. 52:7 is fulfilled principally by Jesus Christ not Christ-followers. 
construing the significance of the 'gospel of peace' fits much better

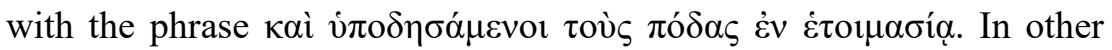
words, while Paul's statements in Ephesians 6:15 are related to Isaiah's new exodus, they are only related in an indirect way, such that believers are called to stand (pun intended) on the victory established through the death and resurrection of Christ.

The next element of the panoply that Paul addresses is the 'shield of faith' (verse 16). According to Paul, this 'shield' will enable believers to 'quench all the flaming arrows of the evil one' (cf. 1 Thess. 5:8; 1 Pet. 5:8-9). It is once again necessary to determine if Paul is referring to the believer's faith or an objective reality. Most scholars seem to favor the subjective reading. ${ }^{49}$ The defensive nature of the imagery, emphasised by Paul himself through his comment about the "flaming arrows of the evil one', certainly gives a measure of support to this interpretation. However, the use of the definite article with the noun

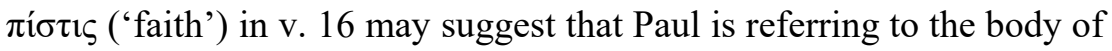
truths associated with the Christian faith. ${ }^{50}$ Ultimately, this may be a situation where subjective application and objective reality need not be separated. That is, even if Paul is emphasising personal trust as a means of standing firm against the attacks of the adversary, some objective set of facts must be trusted. ${ }^{51}$

The call to take up the 'helmet of salvation' in verse 17 represents Paul's next direct evocation of Isaiah 59:17. The most pressing question concerning this piece of the panoply relates to which temporal dimension of 'salvation' Paul is emphasising in this context. Most scholars rightly conclude Paul's stress here (as throughout much of Ephesians) is on the Christ-follower's present experience of salvation. ${ }^{52}$ The 'helmet of salvation' is ultimately to be understood via Paul's discussion of the believer's participation in Christ's triumph within Ephesians 1:20-2:22. There, Paul establishes a logical relationship between Christ's victory over the 'powers' (Eph. 1:20-23), the believer's participation in that victory (Eph. 2:4-6), and the believer's present experience of salvation accomplished by that victory (Eph. 2:5-

49 E.g. Schnackenburg, Epheser, 285; Hoehner, Ephesians, 846.

50 Cf. Best, Ephesians, 601.

51 Cf. Fowl, Ephesians, 207; Barth, Ephesians 4-6, 772-73.

52 E.g. O'Brien, Ephesians, 481; Lincoln, Ephesians, 450-51; pace Muddiman, Ephesians, 293. Paul, however, does not ignore the future dimension of salvation in this letter (cf. Eph. 4:30). 
8). To 'take the helmet of salvation' thus means 'to realise and appropriate one's new identity in Christ, which gives believers power for deliverance from the supernatural enemies on the basis of their union with the resurrected and exalted Lord'. ${ }^{53}$

While Paul has described the believer's battle with cosmic evil primarily in defensive terms to this point in verses 10-17, the believer's primary offensive weapon is depicted in verse $17 \mathrm{~b}$. Believers are to arm themselves with the "sword of the Spirit, which is the word of God'. While there seems to be a strong consensus that this aspect of the panoply should be understood offensively, there is some debate around the meaning of the phrase 'word of God'. According to some interpreters, the phrase refers to Spirit-led confrontations with cosmic evil by Christ-followers through the use of Scripture, similar to the manner in which Jesus engaged with Satan during his period of testing in the wilderness (cf. Matt. 4:1-11; Luke 4:1-13). ${ }^{54}$ Other scholars argue the phrase 'the word of God' refers to the proclamation of the good news of Jesus Christ (cf. 1 Pet. 1:25). ${ }^{55}$ Of these two options, the latter makes the most sense within the context of this letter. The noun $\dot{\rho} \tilde{\eta} \mu \alpha$ only occurs one other time in Ephesians and there in verse 5:26 it almost certainly refers to the gospel of Jesus Christ. ${ }^{56}$ The synonymous relationship between the nouns $\dot{\rho} \tilde{\eta} \mu \alpha$ and $\lambda$ ó $\gamma_{0} \varsigma$ must also be accounted for (e.g. 2 Cor. 2:17; 4:2; Eph. 1:13; Col. 1:25; 1 Thess. 2:13; Titus 1:3). Given how frequently Paul uses the noun $\lambda$ ó $\gamma$ os to refer to the gospel, this also suggests that the phrase $\dot{\rho} \tilde{\eta} \mu \alpha$ $\theta \varepsilon$ vo in Ephesians 6:17 refers to the announcement of the gospel.

In light of the link between new creation and the mission of the Church within this letter, it is natural to consider now how the proclamation of the gospel should be understood offensively. When these factors are considered (principally on the basis of Paul's statements in Ephesians 1:10, 23; 4:7-16), it becomes evident that wielding the 'sword of the Spirit' in Ephesians 6:17 accomplishes more than the salvation of lost sinners, or even victory over the forces of cosmic evil. More specifically, when read within the context of the

53 Arnold, Ephesians, 460.

54 E.g. Hoehner, Ephesians, 853; Talbert, Ephesians and Colossians, 166.

55 E.g. Thielman, Ephesians, 429; Fowl, Ephesians, 208; Sellin, Epheser, 484; Lincoln, Ephesians, 451. Arnold (Ephesians, 462-63) suggests both of these interpretations are valid.

56 Given how strongly the context emphasizes the religious significance of Christ's death, it is natural to understand the noun $\dot{\eta} \eta \mu \alpha \tau \iota$ as a reference to the gospel. 
whole letter, the 'sword of the Spirit' also serves to extend Christ's victory and the new creation. ${ }^{57}$ This process of extending Christ's victory is expressed through the present tense participle $\pi \lambda \eta \rho 0 v \mu \varepsilon$ vov in Ephesians 1:23 and is ultimately the means by which the anakephalaiossis of all things is achieved post-Calvary. Again, the gospel is clearly linked with new creation in Ephesians 1:7-10 and the church is understood as Christ's earthly representative and the means by which his victory over the 'powers' is extended in Ephesians 1:23. ${ }^{58}$ Given that Ephesians 6:10-17 addresses the church's conflict with the 'powers', it is natural to read the proclamation of the gospel implied in Ephesians 6:17 in close relation to the portrait of the church in Ephesians 1:23. This is especially the case since Ephesians 6:10-17 depicts believers as 'divine warriors', who continue Christ's conflict with cosmic evil. Furthermore, the presence of the phrase $\tau \grave{\alpha} \pi \alpha \dot{v} \tau \tau \alpha$

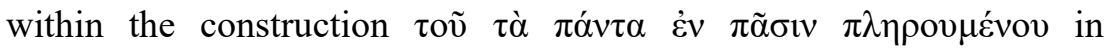
Ephesians 1:23 creates a natural link to Ephesians 1:10. The Isaianic background of Ephesians 6:10-17 is also relevant at this point as it too suggests that the church's conflict with cosmic evil is somehow related to the new creation (cf. Isa. 59:16-62:12). While the victors depicted in the conflict of Ephesians 6:10-17 are of an essentially different nature than the victors depicted in Isaiah and Ephesians 1:19-23, the wider contours of this letter indicate Paul's portrait of the church's struggle with cosmic evil can nonetheless be read through Scripture's narrative pattern of divine warfare. ${ }^{59}$ All of this suggests that the "sword of the Spirit' in Ephesians 6:17 develops significant ideas within the first half of this letter and represents one of the primary means by which the

\footnotetext{
57 The use of the verb 'extend' in this sentence is intended to distinguish between the inauguration of the new creation through Christ's death and resurrection (cf. 2 Cor. 5:14-17) and the process of expanding the impact of Christ's victory through the church's proclamation of the gospel.

58 This may also explain why 'evangelists' are mentioned in Eph. 4:11, again suggesting that the proclamation of the gospel is key to the process of Christ 'filling all things'.

59 Importantly, while Old Testament texts closely follow the pattern of divine conflict ... victory ... temple-building (e.g. Gen. 1-2; Exod. 15:1-17; 39-40; Ps. 29; Isa. $40: 1-11 ; 43: 16-21 ; 52: 7-11)$, this pattern does exhibit a measure of transformation during the Second Temple period, in that, divine conflict and victory are often followed by new creation and the construction of a temple (e.g. 4Q174 2:12-3.13; 1QM 12:9-18). Given that Paul concludes his portrait of new creation in Eph. 2:1-22 by depicting the church as a temple (cf. Eph. 2:19-22), one can conclude that he is following in the footsteps of his Jewish contemporaries by linking new creation with temple-building (cf. 2 Cor. 5:17; 6:16).
} 
church fulfills the mission implicit in Ephesians 1:23. In summary, one may conclude that as the church wields the $\dot{\rho} \tilde{\eta} \mu \alpha \theta \varepsilon$ ov , its victory over cosmic evil leads to the extension of the new creation inaugurated by Christ.

\section{Conclusion}

This article has primarily sought to read Ephesians $6: 10-17$ in light of its Isaianic background, particularly Isaiah 11:5; 52:7-12; 59:15b-20. These three texts from Isaiah's prophecy portray YHWH as a divine warrior fighting for his people and suggest his victory leads to the restoration of Zion/Jerusalem (i.e., the new creation). Importantly, Isaiah 52:7-12 and Isaiah 59:15b-20 suggest that this portrait of YHWH as a divine warrior develops the new exodus theme that is at the core of Isaiah 40-55. I have also argued that Ephesians 6:10-17 should be understood as a metaleptic trope by placing it within the letter's new creation theme. More specifically, I have argued that Ephesians 1:23 and Ephesians 4:7-16 contribute to the letter's new creation theme by suggesting that part of the mission of the church involves extending the new creation inaugurated by Christ's death and resurrection (cf. Eph. 1:10, 20-22). This article has also shown that there are a number of points of contact between Ephesians 6:10-17 and the new creation theme in Ephesians. ${ }^{60}$ Perhaps most importantly, the 'sword of the Spirit' in Ephesians 6:17b likely depicts the church's proclamation of the gospel as an offensive weapon in the war against cosmic evil. When this reference to the spreading of the good news of salvation is read with the allusion to Isaiah 59:17 in Ephesians 6:17a ('the helmet of salvation') and the larger new creation theme in Ephesians, it suggests that the church's preaching of the gospel leads to the expansion of the new creation inaugurated by Christ's victorious death. To 'put on the whole armour of God' in Ephesians 6:10-17 thus involves more than a defensive engagement against the 'wiles of the devil' (v. 11). It also involves the aggressive use of the gospel as the means of combating evil and thereby expanding the influence of the new creation instituted by Christ's death and resurrection.

60 Cf. Eph. 1:7-10; 1:20-2:8; 2:17; 4:15, 21. 